Michael H.M. Dykes MB BCHIR MED, Sze-Chuh Cheng PH D, Harry Cohen MD, Rafael F. Valle MD

\title{
Multiple neuro- muscular blocking agents and reversal in a patient with absent plasma cholinesterase
}

The detailed clinical response of a patient with absent plasma cholinesterase (genotype $E_{I}^{s} E_{l}^{s}$ ) who received tubocurarine ( $3 \mathrm{mg}$ ), succinylcholine (120 mg), pancuronium $(2 \mathrm{mg})$, and reversal with neostigmine $(3 \mathrm{mg})$ is reported. The patient's responses were compared to the responses of a group of patients with genotype $E_{l}{ }^{a}$ $E_{i}{ }^{a}$ evaluated prospectively, and with eight other genotype $E_{i}^{s} E_{i}^{s}$ patients reported in the literature. The present patient demanstrated evidence of a phase II block before and after attempted reversal, suggesting that free succinylcholine was present in her plasma and a mixed black was present at that time. Conservative supportive therapy was continued and a complete recovery resulted five hours and 30 minutes after the succinylcholine administration.

\section{Key words}

NEUROMUSCULAR RELAXANTS: tubocurarine, succinylcholine; ENZYMES: plasma cholinesterase; GENETIC FACTORS: plasma cholinesterase, silent gene.

From the Departments of Anesthesia and Obstetrics and Gynecology, Northwestern University Medical School, and Northwestern Memorial Hospital, Chicago, Illinois.

Address correspondence to: Dr. Dykes, Northwestern Memorial Hospital, Room 360, 303 East Superior Street, Chicago, Illinois 60611 .
The clinical presentation of a patient with absent plasma cholinesterase was first described in 1962. ${ }^{1}$ Reports on seven additional patients ${ }^{2-6}$ who were homozygous for the silent gene (genotype $E_{1}{ }^{s} E_{1}{ }^{s}$ ), included comment on the neuromuscular agents used and the duration of apnoea, but there have been no evaluations of a group of such patients. Spontaneous ventilation was absent or inadequate for nine hours after succinylcholine $(40 \mathrm{mg})$ in one patient. ${ }^{2}$ This was the only patient who received a nondepolarizing neuromuscular blocking agent (tubocurarine $30 \mathrm{mg}$ ) before the condition was recognized, and an anti-cholinesterase agent to reverse the paralysis. This report describes the detailed clinical responses of a patient not previously known to have genotype $E_{1}{ }^{s} E_{1}{ }^{s}$, to pretreatment with tubocurarine $(3 \mathrm{mg})$, paralysis with succinylcholine $(120 \mathrm{mg})$ followed by pancuronium $(2 \mathrm{mg})$, and reversal with atropine and neostigmine. This patient's course is discussed in the light of the responses of the other reported patients with genotype $E_{1} s E_{1}{ }^{s},{ }^{1-6}$ and with a group of patients homozygous for the atypical gene (genotype $E_{1}{ }^{3} E_{l}{ }^{a}$ ). ${ }^{7}$

\section{Case report}

A healthy 32-year-old, $63 \mathrm{~kg}$, gravida 1, para 1 patient was admitted as a day-care patient for laparoscopy and hysteroscopy to evaluate secondary infertility. History, physical examination, laboratory tests and preanaesthetic evaluation were essentially normal except for a history of tonsillectomy and adenoidectomy at three years of age under general anaesthesia, without complication, and extensive orthodontic work with upper and lower braces, about which the patient was greatly con- 


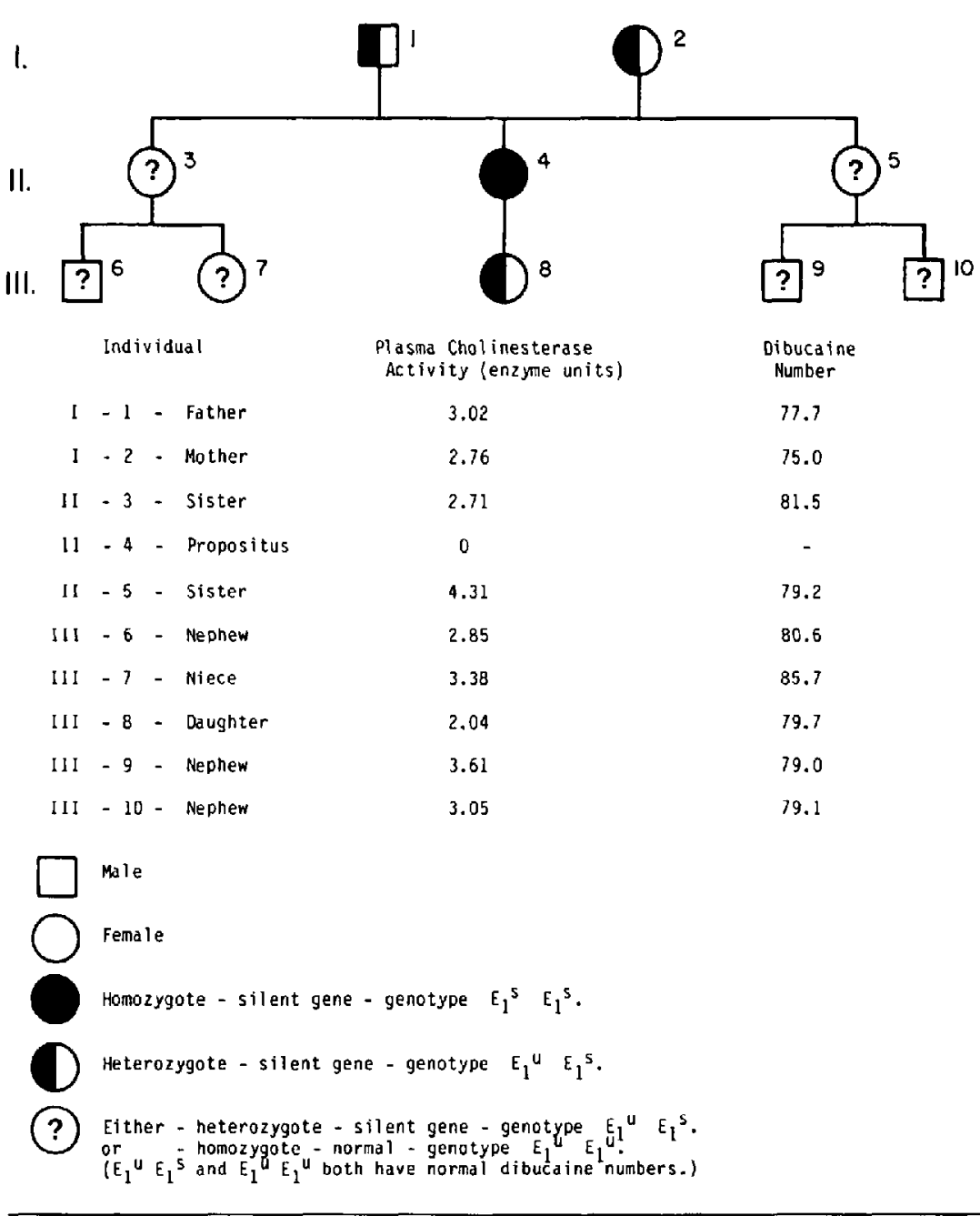

FIGURE The family of the propositus with absent plasma cholinesterase activity.

cerned. She was deemed to be ASA physical status I and was not premedicated.

Anaesthesia was induced at 0930 , following tubocurarine $3 \mathrm{mg}$, with thiopentone $100 \mathrm{mg}$ and succinylcholine $120 \mathrm{mg}$. A $7.5 \mathrm{~mm}$ oral endotracheal tube was passed without trauma and nitrous oxide (4 $\left.L \cdot \min ^{-1}\right)$ and oxygen $\left(2 L \cdot \mathrm{min}^{-1}\right)$ with enflurane 1.5 per cent were started. Twelve minutes later it was observed that a CPK level of $966 \mathrm{mu} \cdot \mathrm{ml}^{-1}$ (normal 0-125) and an SGOT level of $40 \mathrm{mu} \cdot \mathrm{ml}^{-1}$ (normal 0-30), drawn one week prior to her anaesthetic and for which no cause was ever found, had been overlooked during the preanaesthetic evaluation. No twitch could be obtained from stimulation of the right ulnar nerve at the wrist (the neuromuscular stimulator had not been attached prior to succinylcholine administration), and the surgeon was preparing to introduce the trocar.

The patient was examined carefully for signs of hypermetabolism (hot skin, sweating, warm mot- 
tled vasodilated extremities, tachycardia or other dysrhythmia, and hypertension), which were not present, the enflurane was increased to two per cent and pancuronium $2 \mathrm{mg}$ was given because the risk of an abnormal reaction to succinylcholine was believed to be less likely and less dangerous than the morbidity that might attend movement by the patient as the trocar was introduced. The operative procedure and anaesthetic progressed without incident. Upon completion of the procedure at 1045 a neuromuscular stimulator was applied to the left ulnar nerve at the wrist. A twitch with weak poorly sustained tetanus of the flexors of the fifth finger was visible, and reversal was attempted with atropine $1.2 \mathrm{mg}$ and neostigmine $3 \mathrm{mg}$ at 1050 , with the patient receiving only oxygen $5 \mathrm{~L} \cdot \mathrm{min}^{-1}$, in the belief a normal non-depolarizing block was present.

The patient woke up, began diaphragmatic breathing without thoracic excursions, but was unable to raise her head. Ventilation was assisted manually. One hour later she had a stronger twitch but a still poorly sustained tetanus. Her $\mathrm{V}_{\mathrm{T}}$ was $200 \mathrm{ml}\left(3 \mathrm{ml} \cdot \mathrm{kg}^{-1}\right)$; FVC $500 \mathrm{ml}\left(8 \mathrm{ml} \cdot \mathrm{kg}^{-1}\right)$; and negative inspiratory force $-15 \mathrm{mmHg}$. At $1230 \mathrm{her}$ FVC was 1.2 liters $\left(19 \mathrm{ml} \cdot \mathrm{kg}^{-1}\right) ; \mathrm{pH} 7.45 ; \mathrm{PaCO}_{2}$ 32; $\mathrm{PaO}_{2} 370 ;\left(\mathrm{FIO}_{2} 0.99\right.$, assisted ventilation). Edrophonium $5 \mathrm{mg}$ IV resulted in subjective improvement in strength but no change in FVC while a five-minute trial of spontaneous ventilation $\left(\mathrm{FlO}_{2}\right.$ 0.99) resulted in: $\mathrm{pH} 7.42 ; \mathrm{PaCO}_{2} 34 ; \mathrm{PaO}_{2} 432$. At 1500 the patient indicated she had recovered her strength, she could raise her head for over five seconds and had good thoracic excursion. The $\mathrm{VT}$ was $450 \mathrm{ml}\left(7 \mathrm{ml} \cdot \mathrm{kg}^{-1}\right)$; and FVC 1.2 liters (19 $\left.\mathrm{ml} \cdot \mathrm{kg}^{-1}\right)$. She was extubated at 1530 , transferred to a ward, and discharged the following day.

The patient, her parents, her daughter, and both of her sisters, each with two children later gave samples of blood. The patient's blood revealed absent plasma cholinesterase. All other members of her family had normal plasma cholinesterase levels and normal dibucaine numbers (Figure). Plasma cholinesterase activity was determined at $\mathrm{pH} 7.4$ with a pH-stat (Radiometer PHM26, TTT11, TTA31 and SBR2) using a water-jacketed vessel at $37^{\circ} \mathrm{C}$. The reaction mixture, $5.0 \mathrm{ml}$, contained $20 \mu$ mole of acetylcholine, $0.1-0.5 \mathrm{ml}$ of serum, and saline. The amounts of sodium hydroxide used were equivalent to the amounts of acetic acid produced and the amounts of acetylcholine hydro- lyzed. One unit of cholinesterase activity was defined as $1 \mu$ mole of acetylcholine hydrolyzed per minute per $\mathrm{ml}$ of serum at $37^{\circ} \mathrm{C}$. Normal values range from $1.6-3.6$ in the male to $1.0-3.0$ in the female. Dibucaine numbers were determined according to the method of Kalow and Genest. ${ }^{8}$ Normal values are above 70 (average 78.8). The family was counselled about the importance of these findings. The patient's follow-up CPK level was normal.

\section{Discussion}

The results of the plasma cholinesterase determinations in this patient and her relatives are similar to those reported for families in which the $\mathrm{E}_{1}^{\mathrm{s}}$ gene can be traced over two to four generations. ${ }^{3-5,8,10}$ These families indicate the existence of two classes of genotype $\mathrm{E}_{1}{ }^{\mathrm{s}} \mathrm{E}_{1}{ }^{\mathrm{s}}$ which are indistinguishable clinically. "The patients had either no measurable plasma cholinesterase activity or minimal levels (two to eight per cent of the average activity of phenotype $\left.\mathrm{E}_{1}{ }^{\mathrm{u}} \mathrm{E}_{1}{ }^{\mathrm{u}}\right),{ }^{11}$ while their relatives had either normal or low levels of plasma cholinesterase with normal dibucaine numbers (when sought). Under these circumstances the parents and children of the patients with genotype $\mathrm{E}_{1}{ }^{\mathrm{s}} \mathrm{E}_{1}{ }^{\mathrm{s}}$ are heterozygotes with one usual gene and one silent gene (genotype $\mathrm{E}_{1}{ }^{u} \mathrm{E}_{l}{ }^{\mathrm{s}}$ ). Although some such patients (genotype $E_{1}{ }^{u} E_{1}{ }^{5}$ ) may have plasma cholinesterase levels below the "normal" range others may have such levels within the "normal" range, while some normal homozygotes (genotype $E_{1}$ " $E_{1}$ ") can have such levels below the "normal" range. ${ }^{10}$ Clearly there may be much overlap in plasma cholinesterase activity between patients with genotype $\mathrm{E}_{1}{ }^{\mathrm{u}} \mathrm{E}_{1}{ }^{\mathrm{s}}$ and those with genotype $E_{1}{ }^{u} E_{1}{ }^{u}$, all of whom have normal dibucaine numbers. ${ }^{4-10}$ Differentiation may only be possible in those who might have a silent gene through family screening. ${ }^{11}$

The shortest duration of partial paralysis, as evidenced by absent or inadequate spontaneous ventilation, in the nine patients with genotype $E_{l}{ }^{s}$ $\mathrm{E}_{1}{ }^{s}$ noted above, was two hours 30 minutes. The patient who suffered the longest period of partial paralysis (nine hours) received one of the smallest doses of succinylcholine $(40 \mathrm{mg}$ ), but was also the only patient to receive a large dose of a nondepolarizing neuromuscular blocking agent (tubocurarine $30 \mathrm{mg}$ ) before recovery from the succinylcholine paralysis. ${ }^{2}$ 
Viby-Mogensen studied prospectively the response to succinylcholine of patients known to be heterozygous for abnormal $\left(E_{1}{ }^{u} E_{1}{ }^{a}, E_{1}{ }^{u} E_{1}{ }^{5}, E_{1}{ }^{u}\right.$ $\left.E_{1}{ }^{f}, E_{1}{ }^{f} E_{1}{ }^{a}, E_{1}{ }^{f} E_{1}{ }^{s}\right)$ or homozygous for atypical plasma cholinesterase $\left(E_{1}{ }^{a} E_{1}{ }^{a}\right) .^{7,12}$ His studies included patients having six of the nine abnormal genotypes possible with four allelic genes at locus $E_{1}$ controlling synthesis of plasma cholinesterase variants: $\mathrm{E}_{1}{ }^{\mathrm{u}}$ (usual); $\mathrm{E}_{1}{ }^{\mathrm{a}}, \mathrm{E}_{1}{ }^{\mathrm{f}}$ (fluoride resistant); and $E_{1}{ }^{s}$. They included patients with genotype $E_{1}{ }^{a}$ $E_{1}^{a}$ but none with genotype $E_{1}^{s} E_{1}^{s}$.

The response of the present patient will be discussed in the light of the responses of the other eight genotype $\mathrm{E}_{1}{ }^{\mathrm{s}} \mathrm{E}_{1}{ }^{\mathrm{s}}$ patients, and of the group of patients with genotype $E_{1}{ }^{a} E_{1}{ }^{a}$ (reduced plasma cholinesterase activity) as evaluated prospectively by Viby-Mogensen. ${ }^{7}$ As patients with the latter genotype showed marked "fade" of train-of-four (TOF) a phase II block was clearly present. The TOF eventually improved until recovery (TOF 0.7) occurred after two hours and 17 minutes and two hours and 30 minutes in the two patients allowed to recover spontaneously.

The only other genotype $\mathrm{E}_{1} \mathrm{E}_{1}^{\mathrm{s}}$ patient ${ }^{6}$ to have been evaluated with a neuromuscular stimulator showed marked "fade" of TOF and tetanic stimulation indicating a phase II block 45 minutes after $1 \mathrm{mg} \cdot \mathrm{kg}^{-1}$ succinylcholine. Two hours 30 minutes after the succinylcholine, when spontaneous respiration reappeared and the phase II block had wom off (TOF 0.7 ), pancuronium was administered. This was satisfactorily reversed six hours and 30 minutes after the succinylcholine, as measured by TOF $(0.9)$ and sustained tetanus. The present patient also showed evidence of phase II block (poorly sustained tetanus) one hour and 20 minutes after succinylcholine $1.9 \mathrm{mg} \cdot \mathrm{kg}^{-1}$, and again one hour after reversal was attempted with atropine $1.2 \mathrm{mg}$ and neostigmine $3 \mathrm{mg}$. This was clearly a different response to that of the former patient, ${ }^{6}$ but was similar to the response of two $E_{1}{ }^{s} E_{1}^{s}$ patients $^{1-2}$ in whom reversal was attempted in the presence of apnoea or minimal diaphragmatic activity. The findings in the present patient are also consistent with the findings in patients with genotype $E_{1}{ }^{n} E_{1}{ }^{a 7,13}$ in whom the response to reversal depends upon whether there is free succinylcholine in the plasma, the extent to which the block is Phase I or Phase II and the dose of neostigmine.
Viby-Mogensen demonstrated short-lived improvement in TOF with edrophonium $10 \mathrm{mg}$ followed by a sustained improvement with neostigmine $2 \mathrm{mg} 90$ minutes after succinylcholine, but a decrease in the rate of recovery and then an actual decrease in TOF after additional neostigmine $1 \mathrm{mg}$ and $0.5 \mathrm{mg}$ respectively (total dose $3.5 \mathrm{mg}$ ). It is likely that the administration of neostigmine to the present patient actually aggravated her recovery to the extent that free succinylcholine was present in her plasma and a mixed block was in effect at that time. When the equivocal response to edrophonium was observed a conservative approach was adopted.

In summary, the detailed clinical responses of a patient with no plasma cholinesterase (genotype $\mathrm{E}_{1}{ }^{\mathrm{s}}$ $\mathrm{E}_{1}^{\mathrm{s}}$ ) who received tubocurarine ( $3 \mathrm{mg}$ ), succinylcholine (120 $\mathrm{mg})$, pancuronium $(2 \mathrm{mg})$, and reversal has been reported. The data gathered from nine patients with this genotype and two with genotype $E_{1}^{a} E_{1}^{a}{ }^{a}$ studied prospectively suggest that the diagnosis of absence of plasma cholinesterase (genotype $E_{1}^{s} E_{1}^{s}$ ) should be considered in any patient in whom neuromuscular transmission remains abnormal for more than two hours and 30 minutes after succinylcholine administration. Under such conditions the patient should be ventilated artificially until recovery is complete ${ }^{13}$ as an attempt to reverse the neuromuscular block may only aggravate it unless the exact status of the block is known. The only preventive action that can be undertaken in the unsuspected patient is to avoid administering a non-depolarizing neuromuscular blocking agent until neuromuscular transmission has been documented to have returned to normal (phase II block has worn off) after succinylcholine.

\section{References}

1 Hart SM, Mitchell $J V$. Suxamethonium in the absence of pseudocholinesterase. Br J Anaesth 1962; 34: 207-9.

2 Doenicke A, Gurtner Th, Kreutzberg Get al. Serum cholinesterase anenzymia. Acta Anaesthesiol Scand 1963; $7: 59-68$.

3 Dietz AA, Lubrano T, Rubinstein HM. Four families segregating for the silent gene for serum cholinesterase. Acta Genet Basel 1965; 15: $208-17$.

4 Hodgkin WE, Giblett ER, Levine $H$ et al. Complete pseudocholinesterase deficiency: genetic and immu- 
nologic characterization. J Clin Invest 1965; 44: 486-93.

5 Prince LC, Garry PJ, Lubin AH, Silent cholinesterase gene-report of a family. Anesthesiology 1972; 37: 652-3.

6 Oshita S, Sari A, Fujii S, Yonei A. Prolonged neuromuscular blockade following succinylcholine in a patient homozygous for the silent gene. Anesthesiology 1983; 59: 71-3.

7 Viby-Mogensen J. Succinylcholine neuromuscular blockade in subjects homozygous for atypical plasma cholinesterase. Anesthesiology 1981; 55: 429-34.

8 Kalow $W$, Genest $K$. A method for the detection of atypical forms of human serum cholinesterase. Determination of dibucaine numbers. Can J Biochem Physiol 1957; 35: 339-46.

9 Liddell J, Lehmann H, Silk E. A "silent" pseudocholinesterase gene. Nature 1962; 193: 561-2.

10 Pannall PR, Potgieter GM, Raubenheimer MM. Plasma cholinesterase variants - an unexpectedly high incidence of the silent allele. S Afr Med J 1976; 50: 304-6.

11 Whitaker $M$. Plasma cholinesterase abnormalities. Laboratory investigations, Inherited Diseases and Anaesthesia. Edited by Ellis FR. New York, Excerpta Medica, 1981; 105-26.

12 Viby-Mogensen J. Succinylcholine neuromuscular blockade in subjects heterozygous for abnormal plasma cholinesterase. Anesthesiology 1981; 55: 231-5.

13 Bevan DR, Donati F. Anticholinesterase antagonism of succinylcholine phase II block. Can Anaesth Soc J 1983; 30: 569-72.
Résumé

La réponse clinique détaillée d'une patiente présentant une absence de cholinestérase plasmatique (génotype $\mathrm{E}_{1}{ }^{\mathrm{s}}$ $\mathrm{E}_{1}$ ) qui a reçu de la tubocurarine (3 $\left.\mathrm{mg}\right)$, succinylcholine (120 mg), pancuronium (2 $\mathrm{mg}$ ), et renversée par néostigmine (3 $\mathrm{mg}$ ), est rapportée. Les réponses de la patiente ont été comparées avec les réponses d'un groupe de patients présentant un génotype $\mathrm{E}_{1}{ }^{a} \mathrm{E}_{1}{ }^{a}$ évalués prospectivement ainsi qu'avec huit autres présentans un génotype $\mathrm{E}_{1}{ }^{3} \mathrm{E}_{1}{ }^{\mathrm{s}}$ rapportés dans la littérature. La patiente a démontré de l'évidence d'un bloc phase II avant et après une tentative de renversement du bloc, suggérant que la succinylcholine libre était présente dans son plasma et qu'un bloc mixte était présent en même temps. Une thérapie conservatrice de support était continuée et un rétablissement complet s'en est suivi cinq heures et trente minutes après l'administration de succinylcholine. 